\title{
CORRELATION BETWEEN STUDENTS' INTEREST IN WATCHING MUSIC VIDEO AND THEIR LISTENING ABILITY
}

\author{
Nida Rahmatinnisa ${ }^{1}$, Titin Rohaeti ${ }^{2}$ \\ ${ }^{1}$ IKIP Siliwangi \\ ${ }^{2}$ IKIP Siliwangi \\ ${ }^{1}$ nidarahmatinnisa@gmail.com ${ }^{2}$ rohaetitin@gmail.com
}

\begin{abstract}
The purpose of this research was to find out whether or not students' interest in watching music video and their listening ability have a significant correlation. The method used in this research was a quantitative research method. The population of the research is the first grade students of SMK AlHasyimiyah which is located on Jl. Hanjawar Pacet Cianjur. This research was conducted in March 2018 in the 2017/2018 academic year. And the researchers took TKJ class with consist 33 students for the sample out of the population. The data were collected by questionnaire and test, and then the data were analyzed using the correlation analysis. The result of the research showed that students interest in watching music video gave a positive contribution to students listening ability. It can be seen from the result of corrrelation coefficient between the two variables in this resesarch is 0.583 . And the correlation between two variable was significant because sig (2-tailed or 0.000) was lower than 0.05 . In other word that there was significant correlation between students interest in watching music video and their listening ability.
\end{abstract}

Keywords: Correlation, Interest, Music Video, Listening

\section{INTRODUCTION}

Factors' affecting English learning is not only come out from the teacher, but it is also come from the students. Students attitude toward the learning process is become one of the reasons students can achieve the objective of the learning. It is not inferior to others important aspect in learning process, that is students interest. (Kunter et al., 2007), state that Student interest is important for students' performance and a positive attitude among students, all of which are highly beneficial for the future of student. While (Slameto, 2010) states that learning is more successful when dealing with students' interest. Students can get better understanding about the material because he or she tends to love and enjoying that thing higher than the other.

Interest may affect the quality of someone outcomes in a particular field. When people are interested in something, they will do everything to get it. If someone have a high interest of something, they will be do everything even it is very difficult. (James KPOLOVIE, Igho JOE, \& Okoto, 2014) states that Interest is the most powerful affective psychological characteristic and strong emotion knowledge as well as a great positive feeling, a sense of being impressed and motivated to cognitively process information faster and more accurately in addition to traits the most effective treatment of psychomotor like self-regulatory skills, self-discipline, working harder and smarter with best purpose.

Interest is an important factor in a study and to get a good result. The existence of interest has a big role for the learning process, because it can determine the success or failure of students earlier in the study. Students who have a great interest in learning will lead their passion and 
put a full attention to what their want. In addition, (Dalyono, 2009) states "the existence of interest of student into particular lesson will cause the challenge in learning". Therefore, it is better for the student to have big interest in the lesson in order to avoid learning difficulties and the achievement will be better. Language is a mean for people to be able to communicate, express their feeling of sadness and emotion. As English language plays an important role in many aspect of life such as in education, technology, international relationship and so on. Therefore, English language is one of the main subjects that are taught in school because of its importance as an international language.

English language in senior high school involved reading, speaking, writing, and listening. The students are expected to have ability in those language skills. The first step for students to be able to communication with each other is to master the listening skill. According to (Buck, 2001) "a new language learner should learn listening at the initial stage of language learning in the same manner as a child learns a mother language. This is because listening is a skill developed in the very beginning of a child's learning of language". In teaching listening skill, teacher often use English song as a medium. It is because song is interested to hear, and much of people love to listen to it. As explained by (Rosova, 2007) song has a place in the classroom activity to create supporting and friendly atmosphere in language teaching, moreover it is interesting and a helpful learning media.

Songs often come with their music video, it is common when a meaning of the song is hard to understand moreover for foreign language learner, and however a music video helps to explain the message and completed the song. Music video is a short film or video that completes a song and deliver a message in it (Moller, 2011). While (Leonard, 2007) states that "music video as a performance site where artist image is enacted, reinforced, developed or reinvented". Music video is generally designed for the consumption of youth and young adolescent and young adult. The main reason for music video as at its origin was to create publicity and promotion of artist, but now musical video used as a marketing strategy to make profit.

Therefore, a music video or video clip also has its own place, whether to help someone understanding the song or to make the song become more interesting for the listener. And the impact, there is a group of people who tend to collect some music video because it is interesting for them. The preponderance of music video is it can be used as a medium in teaching and learning activity, some students who are audio-visual learners are fond to learn through it and it is might be interesting for the students.

In this research, the researchers want to find out whether is music video can give an effect to the students' listening ability and improve their skill on listening or not. Conducted these problem, the writer proposes to see is there any correlation between students' interest in watching music video and their listening ability.

\section{METHOD}

In conducting this research, the researchers used correlative study to know the correlation between one variable with other variable. The purpose of the correlational research is to find out which variable that are correlate each other. This method was relevant to the research because the research attempted to find out the correlation between the students interest in watching music video and their score in listening ability. The variable in this research are students' interest in watching music video (X) and their listening ability (Y). Moreover, researchers used quantitative research method to collect, analyze and evaluate the data. 
According to (Moleong, 2008) quantitative research is the classification of the research based on the characteristic of the data that have been converted into numbers, statistical, and the result can be measured.

This research was conducted at SMK Al-Hasyimiyah which is located on Jl. Hanjawar Pacet Cianjur. This research was conducted in March 2018 in the 2017/2018 academic year. The population is the first grade at SMK AL-Hasyimiyah. There are three classes at the first grade students, there are TKJ (Computer and Networking Technique), AP (Office Administration), and OTO (Automotive). Each class consists of 28-33 students. While for the sample for this research, the researchers took TKJ class with consist 33 students out of the population. The researchers used questionnaire to collect the data of students' interest toward the music video, and for students' listening ability the instruments was paper-based test, that is fill in the blank lyrics of song.

\section{RESULTS AND DISCUSSION}

\section{Results}

Based on the objective of the study, the data collected was presented in the data distribution. The data of students' interest toward music video and their listening ability were distributed in the form of score. The questionnaire that has been answered by the students were rated using likert-scale, which make it easier for the researchers to score the answers. The possible highest score of students' interest was 100 , and the lowest score was 20 . Refers to the distributed data of students' score in their interest, the researchers found that the highest score was 88 and the lowest score was 48 . The data distribution of the students' interest in watching music video is adopted from (Sudijono, 2008).

\section{Table 1. The Result of Questionnaire Score}

\begin{tabular}{|c|c|c|c|}
\hline Class Interval & Category & Frequency & Percentage \\
\hline $20-57$ & Bad & 3 & $9,09 \%$ \\
\hline $58-78$ & Fair & 25 & $75,75 \%$ \\
\hline $79-100$ & Good & 5 & $15,15 \%$ \\
\hline \multicolumn{2}{|r|}{ Total } & 33 & $100 \%$ \\
\hline
\end{tabular}

Based on the table above, it is can be seen that there are three (9.09\%) students who get the score 20 to 57 and have a bad interest in watching music video, $25(75.75 \%)$ students who get the score 58 to 78 and have a fair interest in watching music video, and $5(15.15 \%)$ students who get the score 79 up to 100 and have a good interest in watching music video. From the table, the researchers conclude that the most of the students have a fair interest in watching music video.

\section{The scores of the students' listening ability}

The data of students' English listening test was collected in the form of scores, and the highest score was 100 and the lowest scores was 30 . The data distribution of students 'listening ability test is adopted from (Haris P, 1970) and can be seen in table 2. 


\begin{tabular}{|c|c|c|c|}
\hline Category & Class Interval & Frequency & Percentage \\
\hline Excellent & $81-100$ & 5 & $15,15 \%$ \\
\hline Good & $61-80$ & 13 & $39,39 \%$ \\
\hline Fair & $41-60$ & 12 & $36,36 \%$ \\
\hline Poor & $21-40$ & 3 & $9,09 \%$ \\
\hline Very Poor & $0-20$ & - & - \\
\hline \multicolumn{2}{|r|}{ Total } & 33 & $100 \%$ \\
\hline
\end{tabular}

Based on the table above, it is can be seen that there are five categories for the result of listening ability, there are excellent category, good category, fair category, poor category, and very poor category. The table shows that there are $5(15.15 \%)$ students who get the score start from 81 up to 100 and have an excellent ability in listening, $13(39.39 \%)$ students who get the score start from 61 to 80 and have a good ability in listening, there are $12(36.36 \%)$ students who get the score from 41 until 60 and they have a fair ability in listening ability, $3(9.09 \%)$ students in poor category because they get score from 21 until 40, and there no students who have a very poor ability.

The researchers proposed this research with a hypothesis, and the hypoyhesis is:

$\mathrm{Ho}=$ there is no a significance relationship between students interest in watching music video and their listening ability.

In a purpose of doing verification to the hypothesis, researchers applied correlation analysis and used raw-score correlation formula to find out the correlation between students' interest in watching music video and their listening ability. Following the analyzed data, it was found that the correlation coefficient was 0.583 . The data are shown in table 3 .

Table 3. The Result of Correlation using SPSS

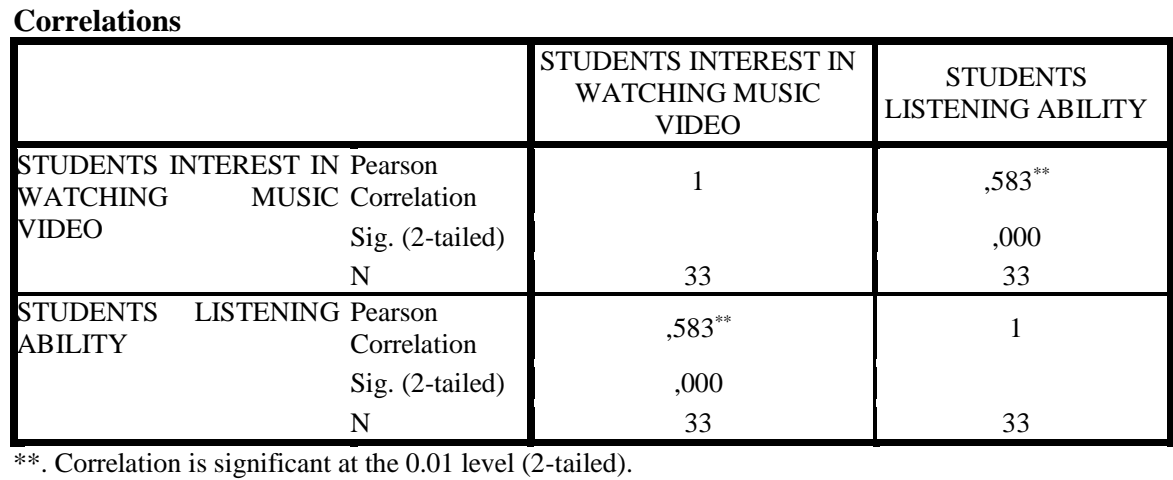

The table show that the sig is 0.000 . It is smaller than 0.05 since the level of significant is 0.05 $(\alpha=0.05)$. Therefore, this table draws the conclusion that the correlation is significant or positive correlation. It means that the Ho is rejected. In conclusion, there is a significance relationship between students interest in watching music video and their listening ability.

\section{Discussion}


Based on the result of calculation data, there was a correlation between students interest in watching music video and their listening ability. The researchers reported the result of data based on data analysis above as follows:

1. Students interest in watching music video gave a positive contribution to students listening ability. It can be seen from the result of corrrelation coefficient between the two variables in this resesarch is 0.583 .

2. The correlation between two variable was significant because sig (2-tailed or 0.000) was lower than 0.05 . in other word that there was significant correlation between students interest in watching music video and their listening ability.

3. As the resutlt of corelation data above, the writer concluded that the null hypothesis (Ho) is rejected whereas alternative hypothesis ( $\mathrm{Ha}$ ) is accepted. It means both of variables were correlated.

\section{CONCLUSION}

Based on findings and interpretation above, the researchers conclude that students' interest in watching music video is influence their listening ability. Since it is proven by this research that interest is play an important role in students' learning process, especially in building students' ability in listening, the researchers suggested to use a music video of English song as a media in teaching English. Since the music video is interesting for the students, it may encourage and establish an enjoyable learning process, hence the students will engage actively and not get bored while learning since they are interested in the lesson.

\section{ACKNOWLEDGMENTS}

The researchers would like to praise Allah SWT for all the grace so that the researchers can accomplish this research and would like to present great honor to IKIP Siliwangi for giving gorgeous study experience. So does the researchers would like to thanks their parents for the best prayer and love.

\section{REFERENCES}

Buck, G. (2001). Assessing Listening. Cambridge: Cambridge University Press.

Dalyono, M. (2009). Psikologi Pendidikan. Jakarta: Rineka Cipta.

Haris P, D. (1970). CELT: a comprehensive English Language Test Speakers of English as a Second Language : Listening specimen set, from L-A. New York: Mc-Graw Hill.

James KPOLOVIE, P., Igho JOE, A., \& Okoto, T. (2014). Academic Achievement Prediction: Role of Interest in Learning and Attitude towards School. International Journal of Humanities Social Sciences and Education, 1(11), 73-100. Retrieved from www.arcjournals.org

Kunter, M., Baumert, J., \& Koller, O. (2007). Effective Classroom Management and the Development of Subject-Related Interest:Learning and Instruction. Orlando.

Leonard, M. (2007). Gender in Music Industry: Rock, Discourse and Girl Power. Aldershot: Ashgate Publishing Ltd.

Moleong, L. J. (2008). Metodologi Penelitian Kuantitatif: Edisi Revisi. Bandung: Rosda Karya. Moller, D. (2011). Redefining Music Video.

Rosova, V. (2007). The Use of Music in Teaching English. Masaryk University. Slameto. (2010). Belajar \& Faktor-Faktor yang Mempengaruhi. Jakarta: Rineka Cipta. Sudijono, A. (2008). Pengantar Evaluasi Pendidikan. Jakarta: Raja Grafindo. 
